\begin{abstract}
Note

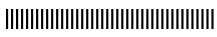

\section{Anomalously High Radon Concentrations in a Dwelling in Okinawa, Japan}

\author{
Atsuyuki Sorimachi ${ }^{*}$, Chutima Kranrod ${ }^{*} * *$, Shinji Tokonami ${ }^{*}$, Tetsuo Ishikawa ${ }^{*}$, \\ Masahiro Hosoda ${ }^{*}$, Miroslaw JaniK ${ }^{* * * *}$, Reina Shingaki ${ }^{* * *}$ and Masahide Furukawa **** \\ * Research Center for Radiation Protection, National Institute of Radiological Sciences \\ 4-9-1 Anagawa, Inage-ku, Chiba-shi, Chiba Pref. 263-8555, Japan \\ **Department of Nuclear Technology, Faculty of Engineering, Chulalongkorn University \\ Payathai Road, Patumwan, Bangkok 10330, Thailand \\ ***Institute of Nuclear Physics PAN \\ ul. Radzikowskiego 152, 31-342 Krakow, Poland \\ ****Department of Physics and Earth Sciences, Faculty of Science, University of the Ryukyus \\ 1 Senbaru, Nishihara-cho, Nakagami-gun, Okinawa Pref. 903-0213, Japan
}

Received August 10, 2009

\begin{abstract}
Short-term measurements of indoor radon concentrations were made in a dwelling in Okinawa, Japan, in which high radon concentrations had been observed in a previous nationwide indoor survey. Measurements were carried out in 4 locations : the bedroom, living room and outdoors. In this study, anomalously high radon concentrations were observed in the 1st-floor bedroom and the mean radon concentration averaged about $400 \mathrm{~Bq} \mathrm{~m}^{-3}$ during the observation period, much higher than Japan's annual average of $15.5 \mathrm{~Bq}$ $\mathrm{m}^{-3}$. A diurnal pattern of extreme fluctuation was found. Furthermore, there was a noticeable spatial distribution of indoor radon concentrations.
\end{abstract}

Key Words : indoor radon, Okinawa, pulse ionization chamber, radon exhalation rate, spatial distribution

\section{Introduction}

Radon $\left.{ }^{222} \mathrm{Rn}\right)$ is a ubiquitous naturally radioactive noble gas. It occurs indoors from the soil and rock beneath and around a dwelling's foundation and from building materials, such as concrete, rock and brick. Radon is known to be one of the most important contributors to human exposure from radiation sources ${ }^{1)}$. The International Committee on Radiological Protection (ICRP) set an action level for residential exposure to radon at an indoor concentration of 200 to $600 \mathrm{~Bq} \mathrm{~m}^{-32)}$.

In Japan, a nationwide indoor radon survey was conducted using Karlsruhe-type passive radon monitors ${ }^{3}$. However, significant thoron $\left.{ }^{220} \mathrm{Rn}\right)$ interference to the measurement of radon was found owing to the high air exchange rate of the passive monitors used for the survey, especially in wooden houses with high thoron concentrations ${ }^{4), 5}$. A second nationwide indoor radon survey was initiated in 1993 using new passive monitors, which were developed to eliminate thoron interference ${ }^{6}$. The annual mean indoor radon concentration in Japan was found to be $15.5 \mathrm{~Bq} \mathrm{~m}^{-3}$. However, there was a house with a high average annual radon concentration, $208 \mathrm{~Bq} \mathrm{~m}^{-3}$, at a level exceeded the ICRP action level. A distinct seasonal variation of indoor radon concentration was clearly 


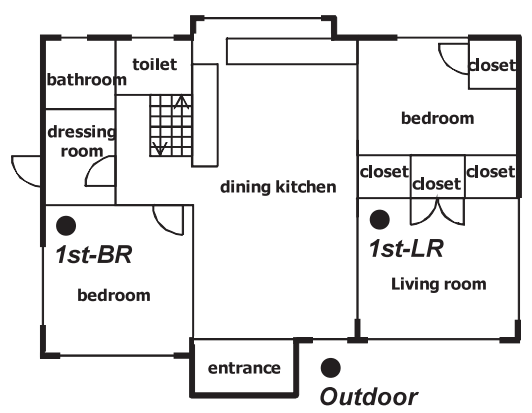

b)

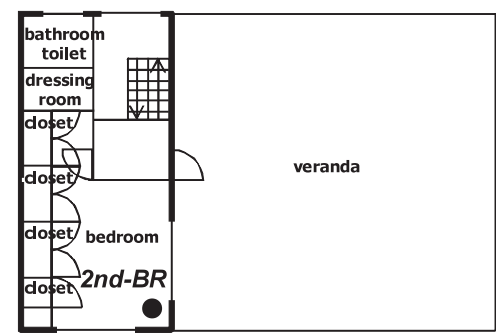

Measuring point

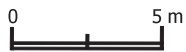

Fig. 1 Floor plan and measurement locations (closed circles) of the (a) 1st floor and (b)

2nd floor in a two-story house.

found out in this dwelling. The concentration level was lower during the summer (July - September), whereas the highest radon concentration was observed in winter (October - December).

In this paper, we carried out short-term measurements to focus on the temporal variation and spatial distribution of indoor radon concentrations in a dwelling with high radon concentrations.

\section{Experimental method}

Indoor and outdoor radon concentrations were measured at a two-story home in Yomitan village, Okinawa prefecture, Japan, where the highest average annual radon concentration was observed in the second nationwide indoor radon survey as noted in the Introduction Section. The walls and floors of each room in the dwelling were made of gypsum board and wood, respectively. The measurements were made during the month of November 2007. Figure 1 shows the floor plan and 4 sampling points: the bedroom and living room on the 1 st floor (1st-BR and 1st-LR), the bedroom on the 2 nd floor (2nd-BR), and outdoors. Table 1 shows the durations of measurement.

Radon concentrations and environmental conditions such as temperature, relative humidity (RH), and air pressure indoors and outdoors were measured at a 1-h interval with a commercially available pulse ionization chamber (AlphaGUARD, Genitron Instruments GmbH, Germany), which was calibrated by the Physikalisch Technische Bundesanstalt (PTB, the German national institute for science and technology) in Germany ${ }^{7), 8}$.

Rainfall measurements were supplemented

Table 1 Arithmetic mean ( \pm standard deviation) of radon concentration, temperature, relative humidity (RH), and air pressure for each sampling location (ranges are given in parentheses)

\begin{tabular}{|c|c|c|c|c|c|c|}
\hline $\begin{array}{l}\text { Location } \\
\text { (symbol) }\end{array}$ & $\begin{array}{l}\text { Measuring duration } \\
(\mathrm{d} / \mathrm{m} / \mathrm{yy} \mathrm{h}: \mathrm{mm})\end{array}$ & $\begin{array}{l}\text { Measuring period } \\
\text { (h) }\end{array}$ & $\begin{array}{l}\text { Radon conc. } \\
\left(\mathrm{Bq} \mathrm{m}^{-3}\right)\end{array}$ & $\begin{array}{l}\text { Temperature } \\
\left({ }^{\circ} \mathrm{C}\right)\end{array}$ & $\begin{array}{l}\mathrm{RH} \\
(\%) \\
\end{array}$ & $\begin{array}{l}\text { Air pressure } \\
(\mathrm{hPa})\end{array}$ \\
\hline $\begin{array}{l}\text { Bedroom on 1st floor } \\
\text { (1st-BR) }\end{array}$ & $\begin{array}{l}\text { 09/Nov./07 22:00 } \\
-29 / \text { Nov./07 09:00 }\end{array}$ & 467 & $\begin{array}{l}397 \pm 207 \\
(44-1119)\end{array}$ & $\begin{array}{l}25.8 \pm 2.0 \\
(22.8-32.0)\end{array}$ & $\begin{array}{l}60.3 \pm 4.7 \\
(45.0-70.5)\end{array}$ & $\begin{array}{l}1010 \pm 4 \\
(998-1017)\end{array}$ \\
\hline $\begin{array}{l}\text { Living room on } 1 \text { st floor } \\
\text { (1st-LR) }\end{array}$ & $\begin{array}{l}\text { 19/ Nov./07 15:00 } \\
-20 / \text { Nov./07 09:00 }\end{array}$ & 18 & $\begin{array}{l}87 \pm 77 \\
(11-198)\end{array}$ & $\begin{array}{l}22.5 \pm 0.3 \\
(21.9-22.9)\end{array}$ & $\begin{array}{l}74.5 \pm 3.9 \\
(69.0-81.5)\end{array}$ & $\begin{array}{l}1015 \pm 1 \\
(1014-1017)\end{array}$ \\
\hline $\begin{array}{l}\text { Bedroom on 2nd floor } \\
\text { (2nd-BR) }\end{array}$ & $\begin{array}{l}\text { 19/ Nov./07 15:00 } \\
-21 / \text { Nov./07 15:00 }\end{array}$ & 48 & $\begin{array}{l}88 \pm 60 \\
(5-190)\end{array}$ & $\begin{array}{l}21.9 \pm 0.7 \\
(21.0-24.0)\end{array}$ & $\begin{array}{l}73.5 \pm 3.0 \\
(66.5-78.5)\end{array}$ & $\begin{array}{l}1016 \pm 1 \\
(1014-1019)\end{array}$ \\
\hline $\begin{array}{l}\text { Outdoor } \\
\text { (Outdoor) }\end{array}$ & $\begin{array}{l}\text { 20/ Nov./07 10:00 } \\
-21 / \text { Nov./07 15:00 }\end{array}$ & 29 & $\begin{array}{l}14 \pm 6 \\
(3-25)\end{array}$ & $\begin{array}{l}21.5 \pm 2.7 \\
(18.9-27.9)\end{array}$ & $\begin{array}{l}69.3 \pm 6.6 \\
(49.3-80.0)\end{array}$ & $\begin{array}{l}1016 \pm 1 \\
(1014-1019)\end{array}$ \\
\hline
\end{tabular}




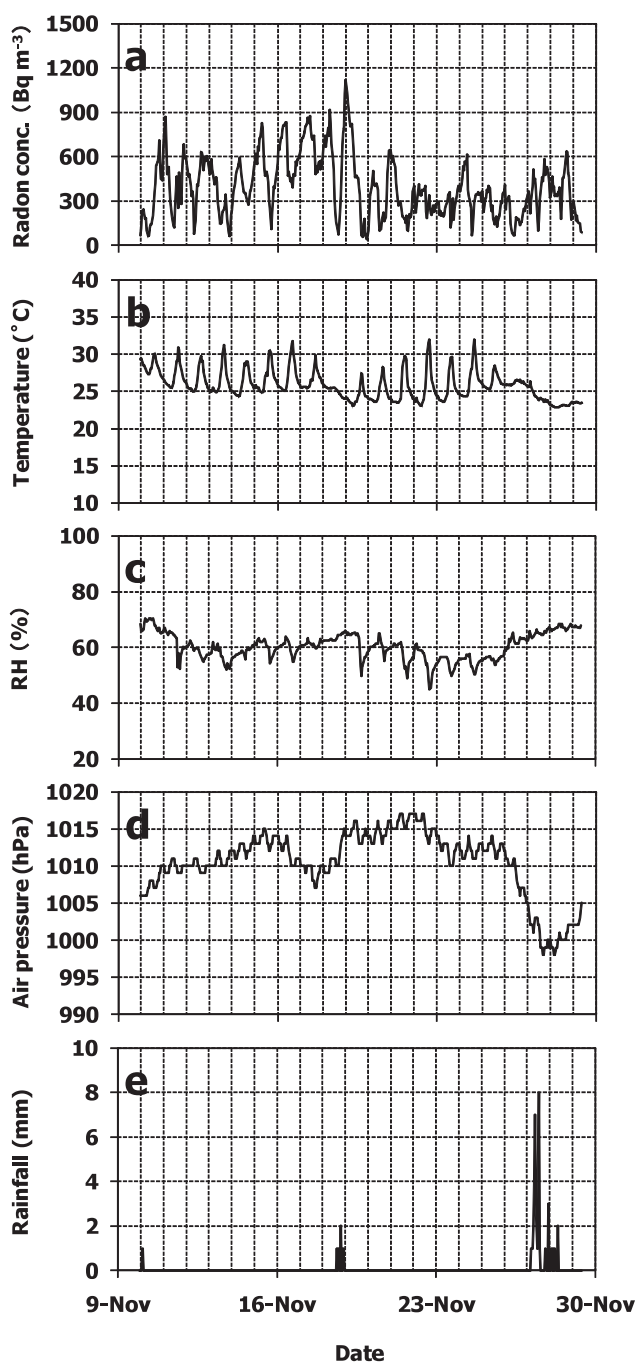

Fig. 2 Variations in (a) radon concentration, (b) temperature, (c) relative humidity $(\mathrm{RH})$, and (d) indoor air pressure in the 1st-BR, and (e) rainfall in Okinawa prefecture from 9 November to 30 November 2007.

by data from the Japan Meteorological Agency's meteorological observatories in Yomitan village, Okinawa prefecture ${ }^{9}$.

Measurement of radon exhalation rate from the soil was made using the accumulation method, which has been described elsewhere in detail ${ }^{10), 11}$. This device is constructed of a large acrylic board of about $1200 \mathrm{~cm}^{2}$ with a $\mathrm{ZnS}(\mathrm{Ag})$ scintillator and a skirt section (volume
$13 \mathrm{~L}$ ) for storing radon gas which releases from the earth surface.

The gamma-ray dose rate in air was also measured using a $1^{\prime \prime} \times 2^{\prime \prime} \mathrm{NaI}(\mathrm{Tl})$ scintillation spectrometer (ss- $\gamma$, Hamamatsu Photonics, Japan) at $1 \mathrm{~m}$ above ground. The readings in $\mu \mathrm{Sv} \mathrm{h}^{-1}$ of this spectrometer were corrected to be those in $\mu \mathrm{Gy} \mathrm{h}^{-1}$ with another well-calibrated instrument using an empirical equation ${ }^{12}$.

\section{Results and discussion}

Figure 2 shows the temporal variations for radon concentration, temperature, $\mathrm{RH}$, and air pressure in the 1st-BR, as well as those for rainfall. The arithmetic mean $( \pm$ standard deviation) radon concentration was $397 \pm 207 \mathrm{~Bq} \mathrm{~m}^{-3}$, much higher than Japan's overall annual average of $15.5 \mathrm{~Bq} \mathrm{~m}^{-3}$ and nearly equal to previously reported values, $320 \mathrm{~Bq} \mathrm{~m}^{-3}$, for the winter season (October - December) ${ }^{6}$. . These values fall in the ICRP's recommended action level of 200 to $600 \mathrm{~Bq} \mathrm{~m}^{-3}$. Figure 3 shows diurnal variation in radon concentration, temperature, $\mathrm{RH}$, and indoor air pressure in the 1st-BR during the measuring period. A diurnal pattern of the indoor radon concentrations was found; there was a tendency that the radon concentrations in nighttime seemed to be higher than those in daytime, which was similar to tendency reported in the literature ${ }^{13), 14}$. On the other hand, the temperature generally started to rise in the afternoon, reached the maximum in the mid-afternoon, and then decreased at night. In general, the daytime and nighttime conditions are mostly unstable and stable, respectively. From Fig. 3 (a), there seemed to increase radon concentrations in nighttime when atmospheric stability conditions become stable and human activities subside. According to many studies, it has shown that the meteoro- 

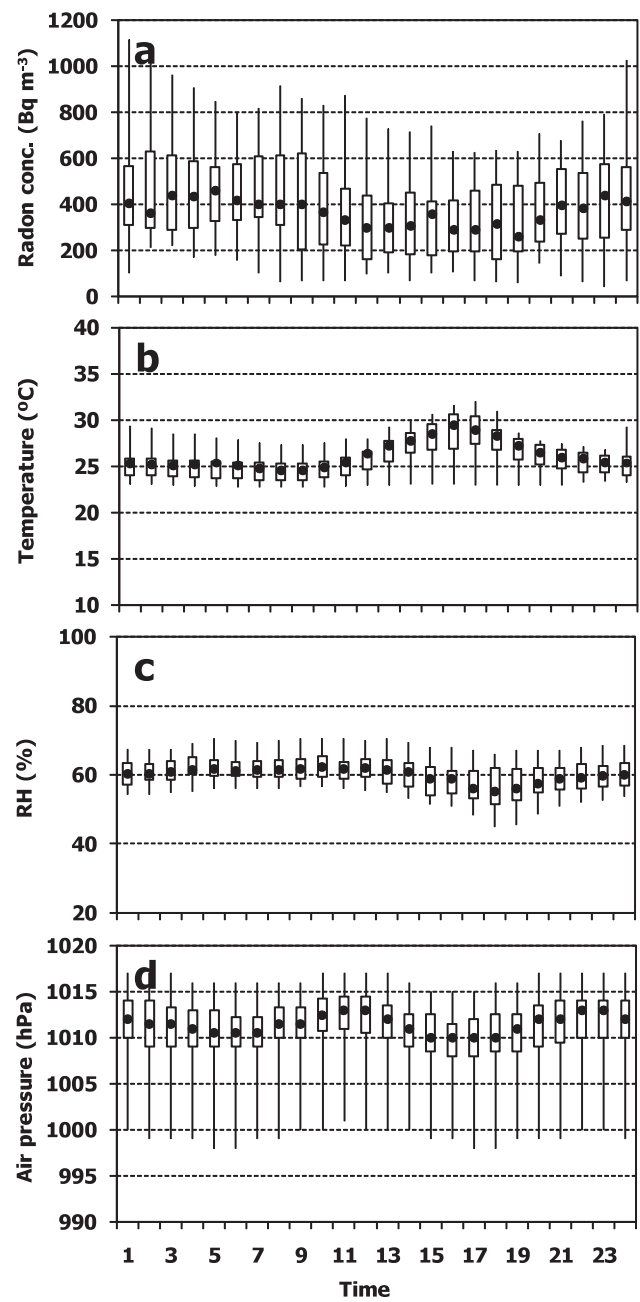

Fig. 3 Diurnal variation in (a) radon concentration, (b) temperature, (c) relative humidity $(\mathrm{RH})$, and (d) indoor air pressure in the 1st-BR during the measuring period. The box corresponds to the interquartile range, and the filled circle in the box is the median. Whiskers extend from minimum to maximum.

logical parameters influence indoor radon concentrations ${ }^{15)-17)}$. From the temporal variations for radon concentration (Fig. 2 (a)), the radon concentrations fluctuated by as much as 1000 $\mathrm{Bq} \mathrm{m}^{-3}$ during the observation period. On $10-$ 11 and $19-20$ November, rapid increases of radon concentrations were observed. These rapid increases may have been related to mete- orological factors. Such high concentrations may be a result of funneling of radon from soil into the house because of heavy rains on those days (Fig. 2 (e)). With a heavy rainfall, the permeability of the soil surrounding the house is greatly reduced, whereas the permeability of the soil beneath the house remains unchanged; as the air pressure falls, soil gas then flows out of the soil into the dwelling at a higher rate than it does out of the soil surrounding the house ${ }^{18}$. On the other hand, there was no increase during a period of the third heavy rain on 27 - 28 November. However, we could not quantitatively estimate such mechanism.

The dependency of indoor radon gas concentration $C_{\mathrm{i}}\left(\mathrm{Bq} \mathrm{m}^{-3}\right)$ can be described by the following equation ${ }^{19)}$ :

$$
C_{\mathrm{i}}=\left(J S / V+C_{0} \lambda_{\mathrm{v}}\right) /\left(\lambda+\lambda_{\mathrm{v}}\right)
$$

where $J$ is the radon exhalation rate of the floor, walls and ceiling of the investigated room $\left(\mathrm{Bq} \mathrm{m}^{-2} \mathrm{~s}^{-1}\right), S$ is the exhaling surface area of the investigated room $\left(\mathrm{m}^{2}\right), V$ is the volume of the room $\left(\mathrm{m}^{3}\right), C_{0}$ is the outdoor radon concentration $\left(\mathrm{Bq} \mathrm{m}^{-3}\right), \lambda_{\mathrm{v}}$ is the ventilation rate $\left(\mathrm{s}^{-1}\right)$, and $\lambda$ is the decay constant of radon $\left(\mathrm{s}^{-1}\right)$. The radon exhalation rate measured in the garden of investigated house was $18.2 \pm 5.9 \mathrm{mBq} \mathrm{m}^{-2}$ $\mathrm{s}^{-1}$, which was nearly equal to the mean values of $16.8 \pm 11.7 \mathrm{mBq} \mathrm{m}^{-2} \mathrm{~s}^{-1} \quad(n=8)$ at the Okinawa's areas, excluding the area investigated in this study ${ }^{20)}$. As a result of the second nationwide indoor radon survey, it was reported that the indoor radon concentrations at Okinawa prefecture, excluding Yomitan village, were $21.7 \pm 19.1 \mathrm{~Bq} \mathrm{~m}^{-3}(n=14)^{21)}$. Accordingly, the indoor radon concentrations for the house investigated in this study were much higher than those obtained from the others in spite of little distinct difference between each radon 


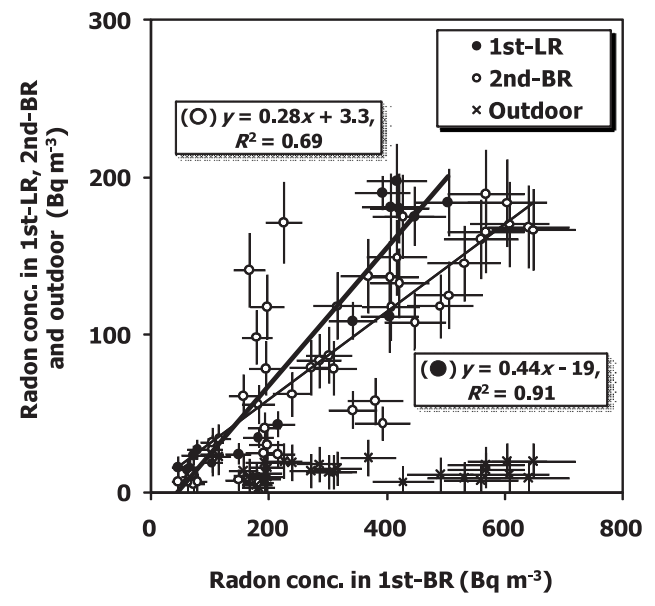

Fig. 4 Relationship between radon concentrations in the 1st-BR and other locations (1st-LR, 2 nd-BR, and outdoor). The bars represent standard deviation.

exhalation rate. Thus the radon exhalation rate from the soil might not lead to such high radon concentration in indoor.

It is generally believed that the indoor radon concentration has a correlation with the terrestrial gamma-ray dose rates ${ }^{22,23)}$. The gamma-

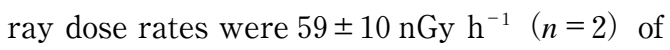
investigated house, while the corresponding mean values at the other Okinawa areas were $82 \pm 12 \mathrm{nGy} \mathrm{h}^{-1} \quad(n=12)^{24}$. Similar to the radon exhalation rate, the terrestrial gamma-ray dose rate in this study seemed to have little relation with high indoor radon concentration. This finding was similar to the tendency observed in Kumamoto city ${ }^{25)}$. Accordingly, anomalously high radon concentrations in a dwelling were probably due mainly to the building materials as a source of indoor radon.

The average indoor radon concentration levels were much higher than outdoor concentration (Table 1). The mean radon concentrations in the 1st-BR were about 4 times higher than the level of those in the 1st-LR and 2nd-BR during the same measuring period, suggesting that spatial distribution may bias the data on radon concentration in indoor surveys.

There were strong correlations among the radon concentrations in each indoor location (Fig. 4). As can be seen in Fig. 4, the indoor radon concentrations in the 1st-BR increased linearly with those in the 2nd-BR $\left(R^{2}=0.69, n=48\right)$ and 1st-LR $\left(R^{2}=0.91, n=18\right)$. Furthermore, a strong correlation between the indoor radon concentrations in the 1st-LR and 2nd-BR was observed $\left(R^{2}=0.77, n=18\right)$. This may be a result of effective mixing of air between the two rooms because there are few obstacles between them (Fig. 1) . On the other hand, the indoor radon concentration in the 1st-BR was not well correlated to outdoor concentration $(p>$ $0.05)$. Although such discrepancies between indoor radon concentration and meteorological factors may be intricately interrelated to diffusion, entry, ventilation, and other factors, it is currently difficult to quantify the relationships.

\section{Conclusion}

In this study, anomalously high radon concentrations in a Japanese dwelling were observed. This may be due to the building materials as a source of indoor radon. A diurnal pattern of extreme fluctuation and a noticeable spatial distribution of indoor radon concentrations were also found. Consequently, the knowledge obtained in this study, such as the anomalously high radon concentrations and its noticeable spatial distribution in a Japanese dwelling, helps us to ascertain such high radon concentrations and the factors that affect them and to take measures against high radon concentrations.

\section{References}

1) UNSCEAR, Sources and Effects of Ionizing Ra- 
diation. United Nations Scientific Committee on the Effects of Atomic Radiation, New York, USA (1993)

2) International Committee on Radiological Protection(ICRP), Protection Again at Radon-222 at Home and at Work, ICRP Publication 65, Annuals of the ICRP, 23, Pergamon, Oxford (1993)

3) Fujimoto, K., Kobayashi, S., Uchiyama, M., Doi, M. and Nakamura, Y., Nationwide indoor radon survey in Japan, Jpn. J. Health Phys., 32, 41-51 (1997) (in Japanese with English abstract)

4) Doi, M., Fujimoto, K., Kobayashi, S. and Yonehara, H., Spatial distribution of thoron and radon concentrations in the indoor air of a traditional Japanese wooden house, Health Phys., 66, 43-49 (1994)

5) Yonehara, H., Aoyama, T., Radford, E.P., Kato, H. and Sakanoue, M., Radon concentrations in residential housing in Hiroshima and Nagasaki, Health Phys., 68, 683-688 (1995)

6) Sanada, T., Fujimoto, K., Miyano, K., Doi, M., Tokonami, S., Uesugi, M. and Takata, Y., Measurement of nationwide indoor Rn concentration in Japan, J. Environ. Radioact., 45, 129-137 (1999)

7) Ishimori, Y., Ishikawa, T. and Tokonami, S., Radon intercomparison experiment at PTB in Germany, Jpn. J. Health Phys., 39, 263-267 (2004)

8) Ishikawa, T., Tokonami, S., Kobayashi, Y., Sorimachi, A., Yatabe, Y. and Miyahara, N., Evaluation of gas-filled ionization chamber method for radon measurement at two reference facilities, The American Institute of Physics (AIP) Conference Proceedings Series, 1034, 423-426 (2008)

9) Japan Meteorological Agency, data available at http://www.jma.go.jp/jma/index.html (browsing : 22 May 2008)

10) Shimo, M., Saegusa, J., Tsujimoto, T., Yamasaki, K. and Yamauchi, T., Development of in-Situ type radon/thoron exhalation rate measuring system, Bulletin of Gifu College of Medical Technology, 10, 19-26 (1994) (in Japanese)

11) Saegusa, J., Yamasaki, K., Tsujimoto, T., Yamauchi, T. and Shimo, M., Development of an apparatus for measuring ground exhalation rates of ${ }^{222} \mathrm{Rn}$ and ${ }^{220} \mathrm{Rn}$, Environ. Int., 22, 483-490
(1996)

12) Furukawa, M. and Tokonami, S., Distribution of absorbed dose rate in air because of terrestrial gamma radiation in Miyako-jima, Okinawa Prefecture, Japan, Jpn. J. Health Phys., 36, 195-206 (2001) (in Japanese with English abstract)

13) Kobayashi, Y., Tokonami, S., Narazaki, Y., Zhuo, W. and Furukawa, M., Enhanced indoor radon concentration by using radon-rich well water in a Japanese wooden house in Fukuoka, Japan, $J$. Radioanal. Nucl. Chem., 266, 389-396 (2005)

14) Yasuoka, Y., Ishikawa, T., Tokonami, S., Takahashi, H., Sorimachi, A. and Shinogi, M., Radon mitigation using an air cleaner, J. Radioanal. Nucl. Chem., 279, 885-891 (2009)

15) Porstendörfer, J., Butterweck, G. and Reineking, A., Daily variation of the radon concentration indoor and outdoors and the influence of meteorological parameters, Health Phys., 67, 283-287 (1994)

16) Yu, K.N., Young, E.C.M. and Li, K.C., A study of factors affecting indoor radon properties, Health Phys., 71, 179-184(1996)

17) Merril, E.A., and Akbar-Khanzadeh, F., Diurnal and seasonal variations of radon levels, effects of climatic conditions, and radon exposure assessment in a former uranium metal production facility, Health Phys., 74, 568-573(1998)

18) Nazaroff, W.W. and Doyle, S.M., Radon entry into houses having a crawl space, Health Phys., 48, 265-281 (1985)

19) UNSCEAR, Ionizing Radiation Sources and Biological Effects, United Nations Scientific Committee on the Effects of Atomic Radiation, New York, USA (1982)

20) Unpublished data

21) Japan Chemical Analysis Center, data available at http://search.kankyo-hoshano.go.jp/(browsing : 22 May 2008)

22) Fujimoto, K., Correlation between indoor radon concentration and dose rate in air from terrestrial gamma radiation in Japan, Health Phys., 75, 291-296 (1998)

23) Sugino, M., Minato, S. and Shimo, M., Survey of the natural radionuclides concentrations using a 
car-borne survey method, J. At. Energy Soc. Jpn., 42, 1084-1092(2000) (in Japanese with English abstract)

24) Abe, S., Fujitaka, K., Abe, M. and Fujimoto, K., Extensive field survey of natural radiation in Japan, J. Nucl. Sci. Tech., 18, 21-45(1981)
25) Hosoda, M., Sorimachi, A., Ishikawa, T., Nakamura, Y. and Tokonami, S., Influential factors affecting the enhancement of indoor radon - a case study on Kumamoto city, Jpn. J. Health Phys., 43, 349-353(2008) (in Japanese with English abstract)

\title{
沖縄県で観測された室内における高ラドン濃度
}

\author{
反町篤行*, Chutima KRANROD ${ }^{* * * *}$, 床次眞司*, 石川徹夫*, \\ 細田正洋*, Miroslaw J $\mathrm{JNIK}^{* * * *}$, 新垣玲奈 $* * * *$, 古川雅英**** \\ *独立行政法人 放射線医学総合研究所 放射線防護研究センター \\ 263-8555 千葉県千葉市稲毛区穴川 4-9-1 \\ **Department of Nuclear Technology, Faculty of Engineering, Chulalongkorn University, \\ Payathai Road, Patumwan, Bangkok 10330, Thailand \\ *** Institute of Nuclear Physics PAN \\ ul. Radzikowskiego 152, 31-342 Krakow, Poland \\ $* * * *$ 琉球大学理学部 \\ 903-0213 沖縄県中頭郡西原町字千原 1
}

\begin{abstract}
我が国で行われた全国調査で，室内における高ラドン濃度が観測された沖縄県読谷村において室 内ラドン濃度に関する調査を行った。測定は寝室, 居間, 屋外において行われた。一階の寝室にお いて，観測期間中の平均ラドン濃度は約 $400 \mathrm{~Bq} \mathrm{~m}$-3 であり，我が国の平均室内ラドン濃度 $(15.5$ $\mathrm{Bq} \mathrm{m}^{-3}$ ) よりも非常に大きい值であった。また, 明確な日内変動及び室内ラドン濃度の空間分布 が観測された。
\end{abstract}

